THURSDAY, APRIL 7,1870

\section{THE SOCIETY OF ARTS CONFERENCE}

$$
T^{H}
$$

E Society of Arts is entitled to the thanks of the community for the service it performs in holding from time to time conferences for the discussion of public questions of immediate interest. Technical education, street tramways; the sewage question, and the Chaninelspanning problem, have all been recently discussed in this way. Last Thursday another national movement, of greater importance than even any of those we have named, was brought under discussion at one of these useful gatherings, namely, the Relation of the State to Science,-a movement that could not have a more natural or more influential supporter than the Society whose special province it is to advance the practical application of science to the needs of our daily life:

The Conference was opened by a paper by Colonel Strange, "On the proposed inquiry, by a Royal Commission; into the Relation of thie State to Science." The part which deals with the scope of the intended inquiry we reproduce in another column: we published some time ago a narrative of events.

It is easy to see that in the paper which formed the subject for debate, the writer aimed at giving to the discussion a practical direction, calculated to assist those interested, including the Government, in determining what objects should claim the attention of the Royal Commission which will probably soon be issued. The Conference, though not numerously attended, included many of our most eminent men of science, and the speakers were all of that class. Professor Williamson, of University College; and Dr. Miller, of King's College; addressed themselves chiefly to the educational side of the question, and insisted on the rights of independent teaching of which they are the recognised champions-rights which Colonel Strange in his paper mentions prominently as demanding examination. Professor Williamson forcibly deprecated any cut-and-dried scheme, thus endorsing Colonel Strange's recommendation that the fullest possible inquiry into all existing scientific agencies should be made first and foremost. Dr. Balfour Stewart suggested a very comprehensive classification of scientific work into Observational work, Experimental work not involving time as an essential element, and Experimental work involving time as an essential element. Of these, he stated that the first and last require the permanence and continuity of State institutions, and have been much neglected in England; while the second can to a great extent be achieved by individuals labouring independently. No doubt this classification will more or less form the basis of the scientific system of the future.

The Astronomer Royal, speaking with an evident sense of the weight that must attach to his opinions on such a subject; and in a tone that might almost be called official, announced his belief that much good would come of the proposed Royal Commission. He illustrated the confused state of our scientific officialism by a humorous description of the accounts of the Royal Observatory, of which three distinct sets were required, one for the Admiralty; another in a different form for the Treasury, and a third "to reconcile the other two." He considered that the preserit movement tended to the creation of a salaried Academy, to which he did not seem opposed, though he pointed out that there are some kinds of inquiry which such a body would never have initiated, as for instance the discovery of Neptune, and Mr. Lockyer's solar researches. Dr. Mann, Mr. De la Rue, and the Rev. Arthur Rigg warmly supported the recommendation that the inquiry should be full. Mr. Edwin Chadwick particularly dwelt on the advantage of official concentration in science, in a speech full of practical sagacity. The discussion was summed up most ably by the chairman, Lord Henry Lennox, President of the Society of Arts, who; in responding to a pointed appeal made to him by Mr. Chadwick, told the meeting how, on one occasion, desiring to ask in the House of Commons a question regarding some scientific matter, he found that it affected four different departments, and should therefore elicit a quadruple reply, the horrors of which he evaded by most informally putting the inquiry to the Premier himself. He did not add that his desire for information was gratifiec.

The proceedings of the Conference were brought to a practical issue by the following resolution:- "That this Conference desires emphatically to affirm the conclusion of the British Association for the Advancement of Science, that a Royal Commission to inquire into the relations of the State to Science is very desirable, and to recommend that the scope of the inquiry be made as wide as possible." This motion obviously conveyed the sense of the meeting with accuracy, and it was carried unanimously. The chairman announced that the resolution and a full report of the conference would be forwarded by the Council of the Society of Arts to the Government.

Armed with so competent and united an expression of opinion, following up that already given by the British Association, the Government will, no doubt, invest the Commission with very full powers. A little consideration, indeed, will show that the wider the scope given to the inquiry, the more easy will it be to conduct it. Nothing would be so difficult as to confine inquiry to selected portions of such a subject, all the parts of which are so intimately connected as to preclude the possibility of entering on one without trespassing on those which surround it. The whole field of science must be submitted to a comprehensive survey, before any project for its effectual cultivation can possibly be devised. The plain assertion made in Colonel Strange's paper, that at present we have not even the nucleus of a scientific system, received the tacit assent of the Conference, no speaker thinking it worth while to do more than incidentally illustrate its truth. Comprehensive confusion needing comprehensive remedies must first undergo comprehensive examination. We agree with those who think it will be difficult for the Commission to construct a new and complete system. A good and durable system must, as Dr. Mann expressed it, be built up by degrees-brick by brick, as it were. This work is administrative, not deliberative, and should therefore properly devolve on the Minister entrusted with the Department of Science. If; with the materials furnished by the Royal Commission to his hand, he cannot work them into shape, the course is simple-change him ! 